\title{
Detection of Hepatitis C Virus (HCV) antibodies among HIV Seropositive women attending a Rehabilitation centre.
}

\author{
James. A. Ndako* ${ }^{1}$ E.A.Onwuliri ${ }^{2}$, Bunmi K.Olopade ${ }^{3}$,Debby T. Olaolu ${ }^{1}$ Ilochi \\ Ifeanyi ${ }^{4}$,Josephine O. Awakan ${ }^{1}$, Temitope V. Dojumo ${ }^{2}$, Deborah O. Ogido ${ }^{5}$ \\ ${ }^{l}$ Department of Biological Sciences, Landmark University Omu aran,-Nigeria. \\ ${ }^{2}$ Departments of Pharmaceutics and Pharmaceutical Technology, University of Jos, Nigeria. \\ ${ }^{3 .}$ Department of Biological Sciences, Covenant University Ota,-Nigeria. \\ ${ }^{4}$ Department Medical Laboratory services Landmark University Health Centre, LMU-Omu aran,Nigeria. \\ ${ }^{5}$ Department, of Medical Lab.Services, General Hospital Ajaokuta-Nigeria.
}

\begin{abstract}
Co-infection with human immunodeficiency Virus HIV and (HCV) is becoming a major global problem, leading to increased morbidity and mortality in both developed and developing countries. This research hence examines the risk factors and transmission of HIV and HCV co-infection. Two hundred and ninety (290) subjects were screened, with HCV global immunochromatographic test kit. Possible risk factors to co-infectious status of subject were determined using a well-structured questionnaire. Out of the 290 sera tested, 25 (8.6\%) were positive for HCV antibodies. Considering Age of subjects screened, females aged 11-20 years recorded a high positivity of $3.1 \%,\left(X^{2}=2.755, P\right.$-value $\left.=0.839 ; P>0.05\right)$. Marital status of subjects showed that single subjects recorded 13(4.5\%), $\left(X^{2}=0.679, P\right.$-value $\left.=0.712 ; P>0.05\right)$ positivity compared to married subjects with $4.1 \%$. There were no significant correlations between HCV infection with Age and Marital Status; $P$ - values $=0.839$ and 0.712 respectively (i.e $P>0.05$ ). Significant correlation was found between HCV antibodies and educational status, (Value $x^{2}=7.957, P$-value $=0.047 ; P<0.05$ ). However, Volunteers with secondary school level of education recorded 10(3.4\%) positivity. The result obtained showed that Seroprevalence to HCV antibodies in this study was high, hence the need for its early diagnosis among HIV patients is strongly advocated to reduce the risk of further complications among these subjects.
\end{abstract}

Key Words: Hcv, Antibodies, Hiv, Females.

\section{Introduction}

The Hepatitis $\mathrm{C}$ virus (HCV) is a life threating viral infection of the liver, transmitted primarily through infected blood and blood products. It is a single stranded RNA virus, belonging to the family of flaviviridae.(Wiener et al, 1989).Approximately 170 million people worldwide are chronically infected by the virus. Human immunodeficiency virus (HIV) is also a very important global public health problem, infecting about 33 million people worldwide (UNAIDS, 2008).

Co-infection with human immunodeficiency virus (HIV) and the Hepatitis C virus (HCV) is a growing public health concern. The transmission routes shared by both infections are in similar ways notably through sharing of needles to injection of drugs and possibly unprotected sexual activities. Most studies have shown that HIV infection leads to a more aggressive hepatitis $C$ virus infection and a higher risk of liver damage, eventually leading to cause of death in HIV infected patients (offor et al, 1992).

Apart from the shared routes of transmission, infection with HIV, when present in either HCVtransmitting or HCV-exposed patients, can have a direct effect on the risk of transmission of HCV. The rate of vertical transmission of $\mathrm{HCV}$ is increased about threefold for coinfected mothers, (Polis, et al.,2007),compared to that for HCV-monoinfected ones; this effect may be limited to women with low HCV RNA levels $<10^{6}$ IU/ml,( Mariné-Barjoan et al 2007).Percutaneous exposure of health care workers to blood from coinfected patients was also shown to increase the risk of acquiring HCV, De Carli et al.,2003. Although coinfected individuals have been shown to have a higher prevalence of HCV RNA in cervicovaginal secretions, (Nowicki,et al 2005) and semen, (Briat,et al 2005).

Nigeria belongs to the leading group of countries highly endemic for Viral Hepatitis infection, about $75 \%$ of the Nigerian population is likely to have been exposed to the virus at one time or the other in their life and $7 \%$ of these people might die as a result of its complication (Pilliero, 2002).

Prior to the advent of HIV/AIDS in Nigeria, there was lack of enforcement of regulation guiding blood transmission in many localities; this enhances the indiscriminate blood transfusion practice and dominance of commercial donors among blood donor. Parenteral exposure modes such as intravenous drug use (IVDU) or multiple transfusions have been consistently found to be the most important risk factors for coinfection, 
(Tedaldi.,2003).Available data showed that the prevalence of hepatitis $\mathrm{C}$ virus among local commercial blood donor in Nigeria ranged from 12.3-14.0\% (Ajayi 1992).

Globally, more attention is given to hepatitis C virus -HIV co-infection as a result of its higher frequency of chronic disease. (Piliero, 2002), and more so, hepatitis C virus -HIV co- infection is capable of impairment of the immune system recovery after starting antiretroviral therapy, resulting in therapy complicated treatment.

\section{Material and methods}

Study area

The study was carried out among certified HIV positive female subjects attending Mangu Rehabilitation Center.

\section{Study population}

A total of two hundred and ninety (290) blood samples were obtained from the volunteer female study subjects.

\section{Questionnaire}

A well-structured questionnaire was administered to the volunteer subjects to obtain demographic and other relevant data.

\section{Ethical Clearance and Consent:}

Ethical clearance was obtained from the relevant committee for using humans as study subjects while Informed consent was obtained as a response from the Volunteer subjects recruited for the study.

\section{Sample collection and assay}

$3 \mathrm{ml}$ of blood was collected and placed into a sterile vacutainer tube and allowed to clot.The sera were separated into sterile cryovials and stored at $-20^{\circ} \mathrm{c}$ until further use.

Laboratory test for HCV: The HCV one step Hepatitis C virus Immunochromatographic test strip.

\section{Principles of the test}

The HCV one step Hepatitis C virus test strip (Serum plasma) is a qualitative membrane based immunoassay for the detection of antibody to HCV in serum or plasma. The membrane is coated with recombinant $\mathrm{HCV}$ antigen on the test line region of the strip. During testing, the serum or plasma specimen reacts with the protein coated particles. The mixture migrates upward on the membrane chromatographically by capillary action to react with recombinant HCV antigen and generate a coloured line; Presence of this coloured line indicates a positive result, while its absence indicates a negative result. To serve as a procedural control, a coloured line will always appear at the control line region indicating that proper volume of specimen has been added and membrane wicking has occurred.

\section{Results}

A total of two hundred and ninety samples (290) were collected. The overall result showed that 25 (8.62\%) subjects screened were found to be sero-positive to the HCV while $265(91.4 \%)$ were negative as shown in Table 1 below.

Table 2 shows the age distribution of the subjects screened for HCV antibodies. The highest prevalence was found among those aged 11-20years with $9(3.1 \%)$ while those aged 21-30 years recorded $7(2.2 \%)$. The lowest prevalence was recorded among those age 51-60 years and 71-80 years with $0 .(0.00 \%)$ and $0(0.00 \%)$ respectively.

Table 3 showed prevalence based on marital status, single female subjects had the highest prevalence of $13(4.5 \%)$ while married females with $12(4.1 \%)$. There was no significant relationship between marital status and HCV antibodies in these subject.

Table 4 showed the educational distribution of the females with the highest prevalence to $\mathrm{HCV}$ antibodies found among those with secondary education with a record of 10(3.4\%). Those without formal education had $6(2.1 \%)$. The lowest prevalence were recorded among subjects with at most tertiary education with 4(1.4\%) there was significant relationship between HCV and educational distribution.

Table 5 showed a prevalence based on clinical risk factors, highest prevalence was found among subjects without a record of any risk factors with $11(3.8 \%)$, while those who has had blood transfusion recorded a prevalence of $7(2.4 \%)$. The lowest prevalence was recorded among subject with a history of sexually transmitted disease (STD) with 3(1.0\%) rate of positivity. This was a significant relationship between HCV and clinical risk factors.

Table 6 shows prevalence based on life style. The highest prevalence to HCV antibodies was found among non alcoholics with 11(3.8\%) while individuals that consume local brew alcohol had 6(2.1\%). 
Detection of Hepatitis C Virus (HCV) antibodies among HIV Seropositive women attending...

Table 1: Age Distribution Of Hcv Antibodies Among Hiv Positive Females.

\begin{tabular}{|c|c|c|c|}
\hline Age & No. of Samples Per age Group & No.s Positive (\%) & Nos. Negative (\%) \\
\hline $11-20$ & 107 & $9(3.1)$ & $98(33.8)$ \\
\hline 21.30 & 102 & $7(2.4)$ & $95(32.80)$ \\
\hline $31-40$ & 46 & $5(1.7)$ & $41(14.1)$ \\
\hline $41-50$ & 23 & $3(1.0)$ & $20(6.9)$ \\
\hline $51-60$ & 6 & $0(0.0)$ & $6(2.1)$ \\
\hline $61-70$ & 5 & $1(0.3)$ & $4(1.4)$ \\
\hline $71-80$ & 1 & $0(0.0)$ & $1(0.3)$ \\
\hline Total & 290 & $25(8.6)$ & $265(91.4)$ \\
\hline
\end{tabular}

$\left(\right.$ Value $\mathrm{x}^{2}=2.755$, df 26, P-value $=0.839$, where $\left.\mathrm{P}>0.05\right)$.

Table 2: Distribution Of Hcv Antibodies Based On Marital Status Of Subjects

\begin{tabular}{cccc}
\hline Marital Status & No. of Samples & No.s Positive (\%) & Nos. Negative (\%) \\
\hline Singles & 146 & $13(4.5)$ & $133(45.9)$ \\
Married & 137 & $12(4.1)$ & $125(43.1)$ \\
Divorced & 7 & $0(0.00)$ & $72.4)$ \\
Total & $\mathbf{2 9 0}$ & $\mathbf{2 5}(\mathbf{8 . 6})$ & $\mathbf{2 6 5}(\mathbf{9 1 . 4 )}$ \\
\hline
\end{tabular}

$\left(\right.$ Value $\mathrm{x}^{2}=0.679, \mathrm{df}=2, \mathrm{P}-$ value $=0.712$ where $\left.\mathrm{P}>0.05\right)$

Table 3:Distribution Of Hcv Antibodies Based On Education Status Of Subjects.

\begin{tabular}{cccc}
\hline Education Status & No. of Samples & No.s Positive (\%) & Nos. Negative (\%) \\
\hline Primary & 48 & $5(1.7)$ & $43(14.8)$ \\
Secondary & 126 & $10(3.4)$ & $116(40.0)$ \\
Tertiary & 88 & $4(1.4)$ & $84(29.0)$ \\
No. Education & 28 & $6(2.1)$ & $22(7.6)$ \\
Total & $\mathbf{2 9 0}$ & $\mathbf{2 5}(\mathbf{8 . 6})$ & $\mathbf{2 6 5}(\mathbf{9 1 . 4})$ \\
\hline
\end{tabular}

$\left(\right.$ Value $\mathrm{x}^{2}=7.957, \mathrm{df}=3, \mathrm{P}-$ value $=0.047$ where $\left.\mathrm{P}<0.05\right)$

Table 4: Distribution Of Hcv Antibodies Based On Clinical Risk Factors.

\begin{tabular}{lccc}
\hline Risk Factors & No. of Samples & No.s Positive (\%) & Nos. Negative (\%) \\
\hline Surgery & 58 & $4(1.4)$ & $54(18.6)$ \\
Blood Transfusion & 81 & $7(2.4)$ & $74(25.5)$ \\
Sexually Transmitted Disease(STD) & 98 & $3(1.0)$ & $95(32.8)$ \\
No history of any Risk Factors. & 53 & $11(3.8)$ & $42(14.5)$ \\
Total & $\mathbf{2 9 0}$ & $\mathbf{2 5}(\mathbf{8 . 6})$ & $\mathbf{2 6 5}(\mathbf{9 1 . 4})$ \\
\hline
\end{tabular}

$\left(\right.$ Value $\mathrm{x}^{2}=13.970, \mathrm{df}=3, \mathrm{P}-$ value $=0.003$ where $\left.\mathrm{P}<0.05\right)$

Table 5: DISTRIBUTION OF HCV ANTIBODIES BASED ON TYPE OF ALCOHOL CONSUMED.

\begin{tabular}{lccc}
\hline Type of Alcohol & No. of Samples & No.s Positive (\%) & Nos. Negative (\%) \\
\hline Beer & 54 & $3(1.0)$ & $51(17.6)$ \\
Hot Drink & 29 & $1(0.3)$ & $28(9.7)$ \\
Local & 72 & $6(2.1)$ & $66(22.8)$ \\
Others & 18 & $4(1.4)$ & $14(4.8)$ \\
None & 117 & $11(3.8)$ & $106(36.5)$ \\
Total & $\mathbf{2 9 0}$ & $\mathbf{2 5}(\mathbf{8 . 6})$ & $\mathbf{2 6 5}(\mathbf{9 1 . 4 )}$ \\
\hline
\end{tabular}

$\left(\right.$ Value $\mathrm{x}^{2}=5.954, \mathrm{df}=4, \mathrm{P}-$ value $=0.203$ where $\left.\mathrm{P}>0.05\right)$.

\section{Discussion}

Human immunodeficiency virus (HIV) infection leads to the suppression of the immune system as the virus destroys the CD4 cells that help the host cell immune system to produce immune response to infections (Nelson, 2003). In HIV infected patients, co-infection with Hepatitis C virus (HCV) has been associated with reduced rate of survival (Ockenga et al., 1997).

The increased risk of HCV related advanced liver disease in people with HIV infection makes early diagnosis of HCV a priority (Amin et al., 2004). The desired attention has not been given to the care delivery system largely to lack of information.

In this study, $25(8.6 \%)$ of the female subjects screened were sero-positive for HCV antibody, which is lower compared to a similar study conducted among patients in Brazil with 36.2\% prevalence, (Segurado et al., 2004).

A similar work conducted in USA, recorded 35\% prevalence, (Veruccli et al., 2004), while in a study conducted at India a record of $21 \%$ was observed (Bhattachanya et al., 2003) and that at Cameroon gave a prevalence of $12.1 \%$ (Kobayashi et al., 2002). 
The result of this study showed a higher prevalence of (8.6\%) compared to a similar work done in Jos with a record of $5.7 \%$ prevalence (Inyama et al. 2005).A lower prevalence of (4.0\%) was recorded among female subjects in the work done by Inyama et al., 2005 as compared to this study with a prevalence of 8.6\%. A number of studies have confirmed that age is a factor for disease susceptibility and progression (Veruccli et al., 2004). The highest prevalence was in the age group 11-20 with a prevalence of 3.1\%.This is due to the fact that these age groups constitutes very active individuals in the society and through their social activities and lifestyles could be prone to infection. There was no statistical significance between age group with $\mathrm{HCV}$ antibodies with $\mathrm{P}>0.05$.

There is a high prevalence among both the singles and the married with $4.5 \%$ and $5.1 \%$ respectively. This is so because sexual behaviours are usually considered of secondary importance in determining the risk of HCV infection (Segurado et al., 2004).

Prevalence of $\mathrm{HCV}$ with respect to educational status gave the highest prevalence among those with secondary education with 3.4\%.This is lower compared to the work done by Lohiya et al., 2009 with a prevalence of $9.9 \%$. There was a statistical significant association between HCV and educational status with $\mathrm{P}<$ 0.05. This finding is however revealing as the low level of education might affect the reliability of information regarding the modes of transmission of $\mathrm{HCV}$ in these patients.

Prevalence of $\mathrm{HCV}$ with regards to clinical risk factors showed a high prevalence among those without recorded cases of any risk factors with $3.8 \%$ prevalence.Factors that have been documented as risk factors including: history of blood transfusion, history of STIs apart from HIV, history of surgery, having multiple sex partners, and injecting drug use were also analyzed (Table 4). However there was a statistical significance between clinical risk factors and HCV antibodies among the subjects screened, with $\mathrm{P}<0.05$ in this study High prevalence was also found among those who do not consume alcohol with $3.8 \%$ prevalence; however there is no statistical significance between alcoholic life style and HCV antibodies with $\mathrm{P}>0.05$.

\section{Conclusion}

Therefore, the high prevalence of HCV/HIV co-infection in this study can probably be attributable to lack of adequate information about HCV.This study also showed the importance of routine HCV screening in developing nations. The result obtained portrays the fact of in-adequate information about HCV by the subjects studied. Our findings call for a proper enlightenment campaign on the scourge of this Virus particularly in developing nations. This study equally advocates early screening of HCV antibodies for HIV patients because of the high prevalence recorded in this study.

\section{Reference}

[1]. Ajayi O.I (1992). Risk factor and seron prevalence of hepatitis C antibody in blood donors in Nigeria. East African Med J. 77:41012

[2]. Amin J, Kaye M, Skidmore S, et al. HIV and hepatitis C coinfection within the CAESAR study. HIV Med 5(3):174-179. 2004

[3]. Bhattacharya S, Badrinath S, Hamide A and Sujatha S 2003 Coinfection with hepatitis C virus and human immunodeficiency virus among patients with sexually transmitted diseases in Pondicherry, South India; Indian J. Pathol. Microbiol. 46:495-497

[4]. Briat, A., E. Dulioust, J. Galimand, H. Fontaine, M. L. Chaix, H. Letur-Konirsch, S. Pol, P. Jouannet, C. Rouzioux, and M. LeruezVille. 2005. Hepatitis C virus in the semen of men coinfected with HIV-1: prevalence and origin. AIDS 19:1827-1835.

[5]. De Carli, G., V. Puro, and G. Ippolito. 2003. Risk of hepatitis C virus transmission following percutaneous exposure in healthcare workers. Infection 31(Suppl. 2):22-27.

[6]. Inyama P.U., Uneke C.J., Anyanwu G.I., Njoku O.M., Idoko J.H., Idoko J.A.,(2005): Prevalence of antibodies to HCV among Nigerian patients with HIV infection. Online Journal of Health Allied Science. 2:2.

[7]. Kobayashi M, Ikeda K, Saitoh S, et al (2000). Incidence of primary cholangiocellular carcinoma of the liver in Japanese patients with hepatitis c virus-related cirrhosis. Cancer, 88, 2471-7.

[8]. Lohiya, G., Figueroa, L. \& Lohiya, S. (2007). Bloodborne Pathogens Exposure from Occupational Fingernail Scratches. Journal of the National Medical Association, 99(11), 1271-1275.

[9]. Mariné-Barjoan, E., A. Berrebi, V. Giordanengo, S. F. Favre, H. Haas, M. Moreigne, J. Izopet, J. Tricoire, A. Tran, C. Pradier, and A. Bongain. 2007. HCV/HIV co-infection, HCV viral load and mode of delivery: risk factors for mother-to-child transmission of hepatitis C virus? AIDS 21:1811-1815.

[10]. Nelson M, Browne R, Asboe D, et al. (abstract F12/3) Increasing incidence of acute hepatitis C in HIV positive men secondary to sexual transmission, epidemiology and treatment. 9th European AIDS Conference. Warsaw, Poland. 2003.

[11]. Nowicki, M. J., T. Laskus, G. Nikolopoulou, M. Radkowski, J. Wilkinson, W. B. Du, J. Rakela, and A. Kovacs. 2005. Presence of hepatitis C virus (HCV) RNA in the genital tracts of HCV/HIV-1-coinfected women. J. Infect. Dis. 192:1557-1565.

[12]. Ockenga J, Stoll, M, Tillmann HL, et al. [Coinfection of hepatitis B and C in HIV- infected patients]. Wien Med Wochenschr 147(19-20):439-42. 1997

[13]. Offor E., Ajati OI, Halim NKD,(1992). Epidemiologic study of the serum prevalence of hepatitis B surface antigen (HBsAg ) and HIV-1 in blood donors. Nig J Dis practice 2:42-5.

[14]. Piliero P.J (2002) : Hepatitis C virus and HIV co-infection. AIDS READ 443 (4): 448-51.

[15]. Polis, C. B., S. N. Shah, K. E. Johnson, and A. Gupta. (2007). Impact of maternal HIV coinfection on the vertical transmission of hepatitis C virus: a meta-analysis. Clin. Infect. Dis. 44:1123-1131.

[16]. Segurado AC, Braga P, Etzel A, Cardoso M.R (2004). Hepatitis C virus co-infectionn in a cohort of HIV-infected individuals from Santos, Brazil: seroprevalence and associated factors. AIDS Patients Care STDS 18: 135-143. 
Detection of Hepatitis C Virus (HCV) antibodies among HIV Seropositive women attending...

[17]. Tedaldi, E. M., K. H. Hullsiek, C. D. Malvestutto, R. C. Arduino, E. J. Fisher, P. J. Gaglio, E. R. Jenny-Avital, J. P. McGowan, and G. Perez. (2003). Prevalence and characteristics of hepatitis $C$ virus coinfection in a human immunodeficiency virus clinical trials group: the Terry Beirn Community Programs for Clinical Research on AIDS. Clin. Infect. Dis. 36:1313-1317.

[18]. UNAIDS. (2008). Report on the global AIDS epidemic. UNAIDS, Geneva, Switzerland.

[19]. Verrucli G, Galza L, Manfredi R, Choido F, (2004): HIV and HCV co-infection,

[20]. epidermiology, natural history, therapeutics options and clinical management. Journal of Infectious disease. 32:33-46. 